\title{
Kecernaan Protein Kasar dan Serat Kasar Kambing Peranakan Etawa Jantan yang diberi Pakan Fermentasi Ampas Tahu dan Bungkil Inti Sawit dengan Imbangan yang Berbeda
}

\author{
Digestibility of Crude Protein and Crude Fiber of Male Etawa Crossbreed Goat Fermented \\ Tofu Waste and Palm Kernel Cake with Different Ratio
}

Ghina Yulianti, Dwatmadji, dan Tatik Suteky

Jurusan Peternakan, Fakultas Pertanian, Universitas Bengkulu

Jalan Raya W. R Supratman, Kandang Limun, Bengkulu, 38371A

Corresponding email : ghinayulianti05@gmail.com

\begin{abstract}
The study aimed to evaluate the digestibility of crude protein and crude fiber of male Etawa crossbreed goats fed with fermented tofu waste feed and palm kernel cake with different ratio. This research was conducted in October-November 2018 in the Babatan Village, Sukaraja, Seluma, Bengkulu Province. The design carried out in this study was a completely randomized design (CRD) consisting of 4 treatments and 5 replications. P0: Tofu waste $45 \%$ + Palm kernel cake 0\%, P1: Tofu waste 40\% + Palm kernel cake 5\%, P2: Tofu waste $35 \%$ + Palm kernel cake 10\%, P3: Tofu waste 30\% + Palm kernel cake $15 \%$. The variables observed were crude protein intake and crude protein digestibility, crude fiber intake and digestibility, water intake and environmental factors. The results showed that the administration of fermented tofu waste feed and palm kernel cake had no significant effect (P <0.05) on crude protein digestibility with P0 (70.1\%), P1 (70.5\%), P2 (72.0\%) and P3 (69.8\%). The treatment significantly $(\mathrm{P}<0.05)$ affect on crude fiber digestibility with P0 (49.3\%), P1 (49.6\%), P2 (52.3\%) and P3 (30.1\%). It can be concluded that the provision of fermented tofu waste feed and palm kernel meal increased the digestibility of crude fiber and did not increase the digestibility of crude protein. However, it provides better crude protein digestibility with a level of tofu waste of $35 \%$ and palm kernel cake of $10 \%$.
\end{abstract}

Key word : Digestibility of PK and SK, Ettawa-Crossbreed Goat, PKC, Tofu Waste

\begin{abstract}
ABSTRAK
Penelitian ini bertujuan untuk mengevaluasi kecernaan protein kasar dan serat kasar kambing Peranakan Etawa jantan yang diberi pakan fermentasi ampas tahu dan bungkil inti sawit dengan imbangan yang berbeda. Penelitian ini dilaksankan pada bulan Oktober-November 2018 di Kelurahan Babatan, Sukaraja, Seluma, Provinsi Bengkulu. Rancangan penelitian yaitu rancangan acak lengkap (RAL) 4 perlakuan dan 5 ulangan. P0 : Ampas Tahu 45\% + Bungkil Inti Sawit 0\%, P1 : Ampas Tahu 40\% + Bungkil Inti Sawit 5\%, P2 : Ampas Tahu 35\% + Bungkil Inti Sawit 10\%, P3 : Ampas Tahu 30\% + Bungkil Inti Sawit 15\%. Variabel yang diamati : konsumsi dan kecernaan protein kasar, konsumsi dan kecernaan serat kasar, konsumsi air minum dan faktor lingkungan. Hasil penelitian menunjukkan bahwa pemberian pakan fermentasi ampas tahu dan bungkil inti sawit berpengaruh tidak nyata $(\mathrm{P}<0,05)$ terhadap kecernaan protein kasar dengan P0 $(70,1 \%), \mathrm{P} 1(70,5 \%), \mathrm{P} 2(72,0 \%)$ dan P3 $(69,8 \%)$. Perlakuan berpengaruh nyata $(\mathrm{P}<0,05)$ terhadap kecernaan serat kasar dengan $\mathrm{P} 0(49,3 \%)$, $\mathrm{P} 1$ $(49,6 \%)$, P2 $(52,3 \%)$ dan P3 (30,1\%). Kesimpulan bahwa perlakuan meningkatkan kecernaan serat kasar dan tidak meningkatkan kecernaan protein kasar. Namun memberikan kecernaan protein kasar yang lebih baik dengan level pemberian ampas tahu 35\% dan bungkil inti sawit sebesar $10 \%$.
\end{abstract}

Kata kunci : Ampas Tahu, BIS, Kambing PE, Kecernaan PK dan SK.

\section{PENDAHULUAN}

Kambing Peranakan Etawa (PE) merupakan ternak ruminansia kecil hasil persilangan antara kambing Etawa dengan kambing lokal Indonesia yaitu kambing Kacang. Umumnya peternak di Provinsi Bengkulu memilih kambing PE dalam pengembangbiakan memiliki tujuan produksi yaitu penghasil susu dan daging (tipe dwiguna). Provinsi Bengkulu mengalami peningkatan produksi daging kambing pada tahun 2016 sampai 2017 yaitu 258 ton/tahun menjadi 274 ton/tahun (Ditjen PKH, 2017). Hal tersebut menjadi peluang usaha penggemukkan kambing Peranakan Etawa di Provinsi Bengkulu. 
Pakan adalah unsur utama yang harus terpenuhi setiap hari untuk mencapai produktifitas ternak yang optimal dari potensi genetik ternak. Faktor produksi yang paling tinggi dalam pengembangbiakan kambing Peranakan Etawa yaitu pakan, berkisar 60$70 \%$ dari biaya keseluruhan pada proses produksi. Salah satu upaya meminimalisir biaya yang dikeluarkan untuk pakan dan efisiensi pakan dengan pemilihan bahan pakan alternatif yang berasal dari pabrik kelapa sawit dan industri pengolahan tahu.

Provinsi Bengkulu mempunyai luasan areal yakni $19.919 \mathrm{~km}^{2}$ setara dengan 1.991.900 ha. Total luasan areal perkebunan kelapa sawit pada tahun 2015 yaitu 191.147 ha dengan total produksi 466.954 ton (Direktorat Jenderal Perkebunan, 2016). Berdasarkan data tersebut terlihat bahwa 10,42\% dari luasan areal Provinsi Bengkulu terdiri dari perkebunan kelapa sawit. Seiring dan sejalan dengan adanya perkebunan kelapa sawit maka keberadaan pabrik pengolahan kelapa sawit semakin meningkat. Produk sampingan industri pengolahan sawit terdiri dari bungkil inti sawit (BIS), lumpur sawit (Solid) dan serat sawit. Salah satu produk sampingan yang potensial digunakan sebagai pakan ternak yaitu bungkil inti sawit. Bungkil inti sawit memiliki kandungan bahan kering 88,0-94,5\%, protein kasar 14,5$19,6 \%$, serat kasar 13,0-20,0\% (Alimon, 2004), bahan organik $85,4 \%$ (Rahman et al., 2013), lemak $9,60 \%$, kalsium $0,36 \%$, fosfor $0,71 \%$ dan energi metabolis $2,087 \mathrm{kkal} / \mathrm{kg}$ (Bintang et al., 1998).

Selain hasil industri pengolahan kelapa sawit, terdapat industri pengolahan tahu dalam skala rumah tangga yang memiliki hasil sampingan berupa ampas tahu yang memiliki kandungan protein yang tinggi dan berpotensi menjadi pakan bagi ternak. Ampas tahu disebut bahan pakan sumber protein karena memiliki protein kasar 2329\% (Mathius dan Sinurat, 2001), lemak $4,93 \%$ (Nuraini, 2009) dan serat kasar 22,65\% (Duldjaman, 2004).

Peningkatan kualitas bahan pakan melalui teknologi fermentasi dengan menggunakan mikroorganisme merupakan cara yang efektif diterapkan pada peternakan semi-modern. Pakan fermentasi bermanfaat bagi ternak guna memperbaiki sistem pencernaan ternak, meningkatkan nafsu makan ternak sehingga pertambahan berat badan yang cepat (Isnainiyati, 2001) dan meningkatkan kandungan vitamin dan mineral (Pelczar dan Chan, 1988 ).

Ampas tahu dan bungkil inti sawit memiliki potensi yang tinggi yang dapat dijadikan pakan alternatif dalam proses penggemukan kambing Peranakan Etawa jantan dan belum banyaknya penelitan mengenai hal tersebut sehingga perlunya dilakukan penelitian mengenai judul "Kecernaan Protein Kasar dan Serat Kasar Kambing Peranakan Etawa Jantan yang diberi Pakan Fermentasi Ampas Tahu dan Bungkil Inti Sawit dengan Imbangan yang Berbeda". Penelitian ini bertujuan untuk mengevaluasi kecernaan protein kasar dan serat kasar kambing Peranakan Etawa jantan yang diberi pakan fermentasi ampas tahu dan bungkil inti sawit dengan imbangan yang berbeda. Diduga pemberian pakan fermentasi ampas tahu dan bungkil inti sawit dengan imbangan yang berbeda dapat meningkatkan kecernaan protein kasar dan serat kasar pada kambing Peranakan Etawa jantan.

\section{METODE PENELITIAN}

Penelitian ini dilaksanakan pada bulan Oktober sampai November 2018 pada tiga tempat yang berbeda. Tempat yang pertama untuk pengukuran serta pengambilan sampel di Kelurahan Babatan, Kecamatan Sukaraja, Kabupaten Seluma, Provinsi Bengkulu. Selanjutnya proses penggilingan sampel di Laboratorium Nutrisi Ternak Jurusan Peternakan Universitas Bengkulu dan analisis sampel di Laboratorium Mikrobiologi dan Biokimia PPSHB LPPM IPB Institut Pertanian Bogor, Bogor.

Alat yang digunakan pada penelitian ini yakni timbangan pakan, timbangan analitik, mesin pemotong (chopper), ember, gelas pengukur air, waring, hygrometer, thermometer, sapu lidi, tali, alat tulis dan alat-alat yang dibutuhkan untuk fermentasi yakni alat pres, kantong plastik, gelas ukur, 
Suntikan (spuit), plastik alas warna hitam, terpal, gloves dan tali plastik.

Bahan yang digunakan yaitu kambing Peranakan Etawa jantan sebanyak 20 ekor dengan berat badan rata-rata $20,46 \pm 1,71 \mathrm{~kg}$ daun ubi kayu, ampas tahu, lumpur sawit, bungkil inti sawit, dedak padi, air dan EM4.

\section{Rancangan Percobaan}

Rancangan percobaan pada penelitian ini adalah rancangan acak lengkap (RAL) yang terdiri dari 4 perlakuan dan 5 ulangan pada setiap perlakuan sebagai berikut:

$\mathrm{P} 0=$ Ampas Tahu 45\% + Bungkil Inti Sawit 0\%

P1 = Ampas Tahu 40\% + Bungkil Inti Sawit 5\%

$\mathrm{P} 2=$ Ampas Tahu 35\% + Bungkil Inti Sawit 10\%

P3 = Ampas Tahu 30\% + Bungkil Inti Sawit 15\%

Semua perlakuan ditambahkan dengan dedak sebanyak 20\%, lumpur sawit fermentasi $25 \%$ dan daun ubi kayu fermentasi sebanyak $10 \%$.

Pada penelitian ini menggunakan model matematika pada setiap observasi menurut Astuti (2007) sebagai berikut:

$$
Y i j=\mu+{ }_{\beta} i+E i j
$$

Dimana:

Yij = Nilai pengamatan pada perlakuan ke-I dan ulangan ke-j

$\mu \quad=$ Nilai rataan umum dari perlakuan

${ }_{\beta} \mathrm{i} \quad=$ Pengaruh perlakuan ke-i

Eij = Galat pada perlakuan ke-I dan ulangan ke-j

\section{Persiapan Kandang}

Kandang yang digunakan adalah kandang individu yang disiapkan sebanyak 20 buah dengan ukuran kandang panjang 100 $\mathrm{cm}$, lebar $50 \mathrm{~cm}$ dan tingginya $115 \mathrm{~cm}$.
Bahan pembuat kandang dari kayu dan bambu pada bagian lantai kandang serta dilengkapi dengan tempat pakan sedangkan tempat minum menggunakan ember plastik dan waring pada sisi kanan kiri kandang individu serta tempat penampung feses bagian bawah kandang.

\section{Persiapan pakan}

Persiapan pakan ampas tahu sebelum fermentasi dilakukan penggurangan kandungan air dengan menggunakan alat penggepres. Kemudian ampas tahu, bungkil inti sawit, lumpur sawit, daun ubi kayu ditimbang dan selanjutnya dilakukan fermentasi anaerob per bahan pakan dengan menggunakan fermentor yaitu Effective Microorganisme-4 (EM4). EM4 yang digunakan sebanyak $1 \mathrm{ml} / 1000$ gram pakan. Fermentasi dilakukan selama 7 hari.

Komposisi bahan pakan penyusun ransum berdasarkan berat segar selama penelitian dapat dilihat pada Tabel. 1

Tabel 1. Komposisi bahan penyusun ransum

\begin{tabular}{clcccc}
\hline \multirow{2}{*}{ No } & \multirow{2}{*}{ Bahan Pakan } & \multicolumn{4}{c}{ Perlakuan } \\
\cline { 3 - 6 } & & P0 & P1 & P2 & P3 \\
\hline 1 & Ampas tahu & 45 & 40 & 35 & 30 \\
2 & Bungkil inti & 0 & 5 & 10 & 15 \\
& sawit & & & & \\
3 & Lumpur sawit & 25 & 25 & 25 & 25 \\
4 & Dedak padi & 20 & 20 & 20 & 20 \\
5 & Daun ubi kayu & 10 & 10 & 10 & 10 \\
\hline \multirow{2}{*}{ Jumlah Total (\%) } & 10 & 10 & 10 & 10 \\
& 0 & 0 & 0 & 0 \\
\hline
\end{tabular}

Kandungan nutrien bahan pakan penyusun ransum selama penelitian dapat dilihat pada Tabel 2, sedangkan Kandungan nutrien ransum selama penelitian dapat dilihat pada Tabel 3 .

Tabel 2. Kandungan nutrien bahan pakan

\begin{tabular}{lcccc}
\hline & $\mathrm{BK}(\%)$ & $\mathrm{BO}(\%)$ & $\mathrm{PK}(\%)$ & $\mathrm{SK}(\%)$ \\
\hline Ampas tahu & 93,82 & 93,54 & 20,31 & 16,77 \\
Bungkil inti sawit & 94,22 & 93,85 & 14,80 & 16,24 \\
Lumpur sawit & 91,57 & 89,32 & 13,74 & 22,68 \\
Dedak padi & 91,07 & 87,00 & 10,01 & 14,60 \\
Daun ubi & 93,08 & 92,03 & 24,68 & 18,17 \\
\hline
\end{tabular}

Hasil analisis laboratorium Mikrobiologi dan Biokimia PPSHB LPPM IPB (2019) 


\begin{tabular}{lcccc}
\hline & \multicolumn{4}{c}{ Perlakuan } \\
\cline { 2 - 5 } & P0 $(\%)$ & P1 $(\%)$ & P2 $(\%)$ & P3 $(\%)$ \\
\hline BK (Bahan Kering) & 93,14 & 92,30 & 91,51 & 91,55 \\
BO (Bahan Organik) & 87,62 & 89,39 & 90,25 & 90,21 \\
PK (Protein Kasar) & 13,50 & 13,51 & 13,53 & 13,54 \\
SK (Serat Kasar) & 18,40 & 17,22 & 17,12 & 17,06 \\
\hline
\end{tabular}

Hasil analisis laboratorium Mikrobiologi dan Biokimia PPSHB LPPM IPB (2019)

\section{Penanganan ternak}

Penanganan ternak pada penelitian ini dimulai dengan pemilihan kambing yang berdasarkan berat badan rataan yang hampir sama sebelum dilakukannya penelitian. Kemudian menempatkan kambing pada kandang individu yang telah disiapkan, sebelumnya kandang telah dibersihkan. melakukan masa adaptasi ternak terhadap pakan dengan formulasi penelitian tanpa bungkil inti sawit 20 hari, terhadap pakan dengan formulasi lengkap dengan menggunakan bungkil inti sawit selama 10 hari dan waktu pengumpulan sampel penelitian selama 7 hari.

\section{Koleksi ransum pemberian dan sisa}

Pengambilan sampel ransum dan sisa ransum dilakukan setiap hari selama fase sampling sebanyak \pm 50 g. Perhitungan konsumsi pakan dilakukan setiap hari dan pengukuran yang dimulai pukul 06.30 WIB sampai dengan selesai. Cara perhitungan konsumsi ransum dengan menimbang total ransum yang diberikan dan sisa ransum per ekor ternak. Konsumsi setiap ekor ternak diperoleh dengan cara mengurangkan total ransum yang diberikan dengan sisa ransum. Sampel ransum pemberian dan sisa dikeringkan, selanjutnya melakukan proses komposit dan melakukan pengilingan sampel untuk dianalisis kandungan protein kasar dan serat kasar.

\section{Koleksi feses}

Koleksi feses dengan menggunakan waring untuk menampung feses yang jatuh dari kandang kemudian ditimbang sehingga diketahui berat feses seluruhnya dan mengambil $\pm 10 \%$ dari total produksi feses untuk dijadikan sampel penimbangan. Pengukuran sampel dilakukan setiap hari dimulai pada pukul 06.30 WIB sampai dengan selesai. Sampel dikeringkan yang kemudian digiling, selanjutnya melakukan proses komposit dan melakukan pengilingan sampel untuk dianalisis kandungan protein kasar dan serat kasar.

\section{Konsumsi dan kecernaan protein kasar} Konsumsi dan kecernaan Protein Kasar dihitung berdasarkan rumus:

- Konsumsi Protein Kasar (g/ekor/hari)

$$
\text { Konsumsi PK }=\begin{array}{ccc}
\text { PKpakan } & & \text { PK } \\
\text { yang } & - & \text { pakan } \\
\text { diberikan } & & \text { sisa }
\end{array}
$$

- Kecernaan Protein Kasar

PK dikonsumsi - PK

$$
\text { Kecernaan PK }=\frac{\text { feces }}{\text { PK dikonsumsi }} \times 100 \%
$$

\section{Konsumsi dan kecernaan serat kasar}

Konsumsi dan kecernaan Serat Kasar dapat dihitung dengan rumus:

- Konsumsi Serat Kasar (g/ekor/hari)

$$
\text { Konsumsi SK }=\begin{array}{ccc}
\text { SK pakan } & & \text { SK } \\
\text { yang } & - & \text { pakan } \\
\text { diberikan } & & \text { sisa }
\end{array}
$$

- Kecernaan Serat Kasar

$$
\text { Kecernaan SK }=\frac{\begin{array}{c}
\text { SK dikonsumsi-SK } \\
\text { feces }
\end{array}}{\text { SK dikonsumsi }} \times 100 \%
$$

\section{Konsumsi air minum}

Konsumsi air minum dihitung dengan cara mengurangi air yang diberikan dengan sisa air minum setiap harinya. Air minum diberikan ad libitum. Pemberian air minum dilakukan sesudah pemberian pakan. 


\section{Faktor lingkungan}

Faktor lingkungan yang akan diukur pada penelitian ini adalah temperatur dan kelembaban. Untuk mengukur temperatur yaitu dengan menggunakan termometer ruangan dan untuk mengukur kelembaban yaitu dengan menggunakan hygrometer (Dry and Wet). Pengukuran dilakukan setiap pagi (jam 08.00 WIB), siang (jam 12.00 WIB) dan sore (jam 16.00 WIB) setiap harinya.

\section{Analisis Laboratorium}

Sampel pakan dan feses yang telah dikoleksi, kemudian dihaluskan terlebih dahulu di Laboratorium Nutrisi Ternak Jurusan Peternakan Fakultas Pertanian Universitas Bengkulu, selanjutnya dilakukan analisis laboratorium yaitu berupa analisis proksimat yaitu, protein kasar (PK) dan serat kasar (SK) di Laboratorium Mikrobiologi dan Biokimia PPSHB LPPM IPB Institut Pertanian Bogor, Bogor.

\section{Analisis Data}

Data yang diperoleh ditabulasi kemudian dilakukan analisis data dengan menggunakan sidik ragam (ANOVA). Apabila hasil analisis dari penelitian ini berpengaruh nyata $(\mathrm{P}<0,05) \quad$ maka dilanjutkan dengan uji Duncan's Multiple Range Test (DMRT) untuk melihat perbedaan antara perlakuan. Software yang digunakan adalah Program SPSS for Windows Version 16.

\section{HASIL DAN PEMBAHASAN}

\section{Protein Kasar (PK)}

Rataan konsumsi, produksi feses dan kecernaan protein kasar selama penelitian dapat dilihat pada Tabel 4. Hasil analisis ragam menunjukkan bahwa pemberian ampas tahu dan bungkil inti sawit fermentasi dengan level berbeda berpengaruh nyata $(\mathrm{P}<0,05)$ terhadap konsumsi protein kasar pada kambing Peranakan Etawa jantan. Hasil uji lanjut menunjukkan bahwa $\mathrm{P} 0$ berbeda nyata $(\mathrm{P}<0,05)$ dengan $\mathrm{P} 3$ dan $\mathrm{P} 0$ berbeda tidak nyata $(\mathrm{P}>0,05)$ dengan $\mathrm{P} 1$ dan $\mathrm{P} 2$. Konsumsi protein kasar P0 95,0 g/ekor/hari, P1 95,3 g/ekor/hari, P2 94,1 g/ekor/hari dan P3 83,1 g/ekor/hari. Pemberian bungkil inti sawit dengan level $15 \%$ pada ransum secara nyata menurunkan konsumsi protein kasar. Hal tersebut terjadi dipengaruhi oleh beberapa faktor antara lain palatabilitas ternak.

Rataan konsumsi protein kasar (PK) selama penelitian berkisar antara 83,1-95,3 g/ekor/hari. Hasil penelitian ini lebih tinggi dibandingkan dengan penelitian Hutagalung (2018) konsumsi protein kasar kambing Peranakan Etawa jantan yang diberi konsentrat lumpur sawit dan ampas tahu 77,80-84,09 g/ekor/hari. Konsumsi protein kasar sangat dipengaruhi oleh kandungan nutrisi protein kasar dalam ransum.

Tabel 4. Konsumsi, produksi feses, kecernaan protein kasar dan serat kasar selama penelitian

\begin{tabular}{|c|c|c|c|c|c|}
\hline \multirow{2}{*}{ Variabel } & \multicolumn{4}{|c|}{ Perlakuan } & \multirow{2}{*}{$\mathrm{P}$} \\
\hline & P0 & $\bar{P} 1$ & $\mathrm{P} 2$ & P3 & \\
\hline Konsumsi PK (gram/ekor/hari) & $95,0 \pm 5,62^{\mathrm{a}}$ & $95,3 \pm 6,80^{\mathrm{a}}$ & $94,1 \pm 5,08^{\mathrm{a}}$ & $83,1 \pm 7,81^{b}$ & 0,024 \\
\hline Produksi feses PK (gram/ekor/hari) & $27,8 \pm 2,23^{\mathrm{ns}}$ & $27,3 \pm 2,82^{\mathrm{ns}}$ & $25,9 \pm 2,65^{\mathrm{ns}}$ & $25,6 \pm 2,89^{\mathrm{ns}}$ & 0,240 \\
\hline Kecernaan PK (\%) & $70,1 \pm 3,74^{\mathrm{ns}}$ & $70,5 \pm 3,55^{\mathrm{ns}}$ & $72,0 \pm 1,98^{\mathrm{ns}}$ & $69,8 \pm 1,87^{\mathrm{ns}}$ & 0,643 \\
\hline Konsumsi SK (gram/ekor/hari) & $119,0 \pm 8,45^{\mathrm{a}}$ & $116,1 \pm 8,10^{\mathrm{a}}$ & $113,0 \pm 8,47^{\mathrm{a}}$ & $83,7 \pm 3,16^{\mathrm{b}}$ & 0,000 \\
\hline Produksi feses SK (gram/ekor/hari) & $58,8 \pm 2,99^{\text {ns }}$ & $56,4 \pm 2,93^{\mathrm{ns}}$ & $52,7 \pm 4,37^{\mathrm{ns}}$ & $56,8 \pm 3,09^{\mathrm{ns}}$ & 0,088 \\
\hline Kecernaan SK (\%) & $49,3 \pm 4,68^{\mathrm{a}}$ & $49,6 \pm 4,54^{\mathrm{a}}$ & $52,3 \pm 2,83^{\mathrm{a}}$ & $30,1 \pm 3,47^{\mathrm{a}}$ & 0,000 \\
\hline
\end{tabular}

Keterangan : ns : Non-signifikan. Huruf yang berbeda pada kolom yang sama menunjukkan berbeda nyata $(\mathrm{P}<0,05) . \mathrm{P0}=$ Ampas Tahu 45\% + Bungkil Inti Sawit 0\%, P1 = Ampas Tahu 40\% + Bungkil Inti Sawit 5\%, P2 = Ampas Tahu 35\% + Bungkil Inti Sawit 10\%, P3 = Ampas Tahu 30\% + Bungkil Inti Sawit $15 \%$. 
Cherdthong et al. (2016) menyatakan bahwa konsumsi protein kasar kambing pada fase pertumbuhan yang diberikan pakan bioetanol singkong sebesar $10 \%$ yaitu 83 g/ekor/hari. Hal ini dikarenakan komponen penyusun ransum dan level pemberian yang berbeda dan perlakuan pada bahan pakan mengakibatkan perbedaan konsumsi protein kasar. Carvalho-Castro et al. (2010) yang menyatakan bahwa kandungan protein kasar dalam pakan mempengaruhi kualitas bahan pakan yang diberikan dan konsumsi pakan. Rahman et al. (2013) melaporkan bahwa total konsumsi protein kasar pada kambing PE yang diberi pakan bungkil inti sawit sebesar $1,0 \%$ dari berat berat badan yaitu 58,9 g/ekor/hari. Hasil penelitian tersebut lebih rendah dibandingkan dengan total konsumsi protein kasar pada level pemberian 5\% pada Tabel 4. Hal tersebut terjadi dikarenakan perbedaan spesies kambing dan berat badan kambing Boer 13,5-14,1 kg.

Tinggi maupun rendahnya konsumsi protein kasar dapat menjadi indikator pertumbuhan secara tidak langsung konsumsi sangat mempengaruhi pertambahan berat badan. Teknik pemberian pakan ad libitum meningkatkan aktivitas mikroba rumen dalam mendegradasi pakan, laju fermentasi meningkat, kecernaan bertambah sehingga konsumsi meningkat (Aryanto et al., 2013). Frekuensi pemberian pakan konsentrat memberikan pengaruh terhadap cepatnya proses pencernaan (Allen and Ying, 2012). Pemberian protein pakan ternak ruminansia perlu memperhatikan aspek degradasi dan by-pass protein di dalam rumen, serta kecernaan pasca rumennya (Puastuti, 2005).

Feses merupakan sisa akhir dari proses metabolisme tubuh yang tidak dapat diserap tubuh atau yang tidak dapat dicerna, baik dalam bentuk bakteri, bahan anorganik dan produk fermentasi bakteri (Elita, 2006).

Berdasarkan hasil analisis ragam menunjukkan bahwa pemberian ampas tahu dan bungkil inti sawit fermentasi dengan level berbeda berpengaruh tidak nyata $(\mathrm{P}>0,05)$ terhadap produksi protein kasar dalam feses pada kambing Peranakan Etawa jantan. Rata-rata produksi protein kasar dalam feses pada penelitian ini berkisar antara 25,6-27,8 g/ekor/hari. Rataan produksi protein kasar dalam feses paling tinggi pada P0 yaitu 27,8 g/ekor/hari. Berdasarkan hasil penelitian produksi protein kasar dalam feses lebih tinggi dibandingkan penelitian Hutagalung (2018) dengan rata-rata 18,4521,85 g/ekor/hari. Ditambahkan oleh Yan et al. (2007) bahwa pengeluaran nitrogen melalui feses dipengaruhi berbagai faktor diantaranya yaitu berat badan ternak, konsumsi bahan kering, serat kasar serta kandungan protein dalam ransum

Berdasarkan hasil analisis ragam menunjukkan bahwa pemberian ampas tahu dan bungkil inti sawit fermentasi dengan level berbeda berpengaruh tidak nyata $(\mathrm{P}>0,05)$ terhadap kecernaan protein kasar pada kambing Peranakan Etawa jantan. Morand-Fehr (1981) menyatakan bahwa kisaran koefisien kecernaan protein kasar pada kambing yaitu 23-75\%. Hasil rata-rata kecernaan protein kasar pada penelitian ini berkisar antara 69,8-72,0\%. Rataan kecernaan protein kasar yang tertinggi pada P2 yaitu $72,0 \%$. Hasil tersebut lebih tinggi dari penelitian Aregheore (2000) yang menyatakan bahwa kecernaan protein kasar pada kambing yang diberi pakan tongkol jagung sebesar $70,1 \%$ dan jauh lebih tinggi dibandingkan dengan penelitian Rahman et al. (2013) yang menyatakan bahwa kecernaan protein kasar pada kambing yang diberi pakan bungkil inti sawit sebesar $52,1 \%$.

Hasil penelitian ini sejalan dengan penelitian Cherdthong et al. (2016) yang menyatakan bahwa kecernaan protein kasar bioetanol singkong memiliki rataan $69 \%$. Ditambahkan oleh Gabriel et al. (2018) bahwa kecernaan protein kasar kulit singkong dalam pakan kambing yaitu 50,28\%. Hal tersebut dikarenakan kandungan nutrisi didalam kulit singkong lebih rendah dibandingkan pada daun singkong dan mempunyai kandungan $\mathrm{HCN}$ yang tinggi.

Semakin tinggi koefisien kecernaan protein kasar berbanding lurus dengan peningkatan bobot badan ternak. Kecernaan dapat dipengaruhi oleh beberapa faktor 
seperti komposisi bahan pakan, perbandingan komposisi antara bahan pakan satu dengan bahan pakan lainnya, perlakuan pakan, suplementasi enzim dalam pakan, ternak dan taraf pemberian pakan (McDonald et al., 2002). Gultom et al. (2016) menambahkan bahwa pemberian ransum dengan perlakuan fisik (chooper), biologi (chooper dan Aspergillus niger) dan kimia (chooper dan urea) mempengaruhi kecernaan protein kasar. Paramita et al. (2008) menyatakan secara invivo kualitas bahan pakan yang diberikan dilihat melalui konsumsi dan besarnya nilai kecernaan yakni indikator banyaknya nutrisi yang dapat dimanfaatkan sebagai kebutuhan hidup pokok serta pertumbuhan.

\section{Serat Kasar (SK)}

Hasil analisis ragam menunjukkan bahwa pemberian ampas tahu dan bungkil inti sawit fermentasi dengan level berbeda berpengaruh nyata $(\mathrm{P}<0,05) \quad$ terhadap konsumsi serat kasar pada kambing Peranakan Etawa jantan. Hasil uji lanjut menggunakan DMRT menunjukkan bahwa $\mathrm{P} 0$ berbeda tidak nyata $(\mathrm{P}>0,05)$ dengan $\mathrm{P} 1$ dan $\mathrm{P} 2$, tetapi berbeda nyata $(\mathrm{P}<0,05)$ dengan P3.

Rataan konsumsi serat kasar berkisar antara 83,7-119,0 g/ekor/hari. Rataan konsumsi serat kasar pada Tabel 4 pada P0 lebih tinggi dibandingkan penelitian Hutagalung (2018) yang menyatakan bahwa konsumsi serat kasar dengan pemberian ampas tahu $45 \%$ yaitu 114,64 g/ekor/hari. Teknik pemberian pakan ad libitum meningkatkan aktivitas mikroba rumen dalam mendegradasi pakan, laju fermentasi meningkat, kecernaan bertambah sehingga konsumsi meningkat (Aryanto et al., 2013).

Berdasarkan hasil analisis ragam menunjukkan bahwa pemberian ampas tahu dan bungkil inti sawit fermentasi dengan level berbeda berpengaruh tidak nyata $(\mathrm{P}>0,05)$ terhadap produksi feses dalam serat kasar pada kambing Peranakan Etawa jantan. Rataan produksi feses serat kasar pada penelitian ini berkisar antara 52,7-58,8 g/ekor/hari. Produksi serat kasar dalam feses dipengaruhi dengan kemampuan ternak mendegradasi lignin dalam pakan. Faktor yang mempengaruhi pengeluaran nitrogen melalui feses diantaranya berat badan ternak, konsumsi bahan kering, serat kasar serta kandungan protein dalam ransum (Yan et al., 2007).

Hasil analisis ragam menunjukkan bahwa pemberian ampas tahu dan bungkil inti sawit fermentasi dengan level berbeda berpengaruh nyata $(\mathrm{P}<0,05) \quad$ terhadap kecernaan serat kasar pada kambing Peranakan Etawa jantan. Hasil uji lanjut menggunakan DMRT menunjukkan bahwa $\mathrm{P} 0$ berbeda tidak nyata $(\mathrm{P}>0,05)$ terhadap $\mathrm{P} 1$ dan $\mathrm{P} 2$ tetapi $\mathrm{P} 0, \mathrm{P} 1$ dan $\mathrm{P} 2$ berbeda nyata $(\mathrm{P}<0,05)$ terhadap $\mathrm{P} 3$. Rataan kecernaan serat kasar berkisar antara 30,1-52,3\%. Kambing membutuhkan serat pakan yang cukup untuk aktivitas dan fungsi rumen yang normal. Mikroba rumen memerlukan sumber energi yang diperoleh dengan cara mendegradasikan serat pakan dengan tujuan untuk mendukung hidup pokok, pertumbuhan, laktasi dan reproduksi ternak (Lu et al., 2005). Ibrahim et al. (1995) mengemukakan bahwa kecernaan serat kasar merupakan ciri bahwa kandungan lignin yang tinggi pada hijauan dan konsentrat sehingga mempengaruhi koefisien kecernaan serat kasar.

\section{Konsumsi Air Minum}

Rataan konsumsi air minum selama penelitian dapat dilihat pada Tabel 5 . Pemberian ampas tahu dan bungkil inti sawit fermentasi dengan level berbeda berpengaruh tidak nyata $(\mathrm{P}<0,05)$ terhadap konsumsi air minum pada kambing Peranakan Etawa. Rata-rata konsumsi air minum selama penelitian berkisar antara 511,1 - 616,3 $\mathrm{ml} /$ ekor/hari. Konsumsi air minum tertinggi pada $\mathrm{P} 2$ yaitu $616,34 \mathrm{ml} / \mathrm{ekor} / \mathrm{hari}$ serta yang paling rendah terdapat pada P3 yaitu 511,1 $\mathrm{ml} / \mathrm{ekor} / \mathrm{hari}$. Rataan konsumsi air minum dapat dilihat pada Tabel 5 mendekati hasil penelitian Fisman (2000) kambing Peranakan Etawa yang diberi hijauan gamal dan hay ubi kayu berkisar antara 569-622 ml/ekor/hari. Faktor lain yang mempengaruhi konsumsi air minum yaitu fisiologi ternak dan temperatur lingkungan. 
Tabel 5. Konsumsi minum selama penelitian

\begin{tabular}{|c|c|c|c|c|c|}
\hline \multirow{2}{*}{ Variabel } & \multicolumn{4}{|c|}{ Perlakuan } & \multirow{2}{*}{$\mathrm{P}$} \\
\hline & $\mathrm{P} 0$ & $\mathrm{P} 1$ & $\mathrm{P} 2$ & P3 & \\
\hline \multirow[b]{2}{*}{$\begin{array}{c}\text { Konsumsi air } \\
\text { minum }\end{array}$} & |------------------ & ----------------n & /ekor/hari------- & ----------------- & \\
\hline & $566,6 \pm 84,80^{\mathrm{ns}}$ & $578,8 \pm 61,10^{\mathrm{ns}}$ & $616,3 \pm 62,60^{\mathrm{ns}}$ & $511,1 \pm 43,52^{\mathrm{ns}}$ & 0,182 \\
\hline
\end{tabular}

\section{Mikroklimat}

Hasil pengukuran mikroklimat selama penelitian dapat dilihat pada Tabel 6 .

Tabel 6. Rataan mikroklimat kandang selama penelitian

\begin{tabular}{cccc}
\hline Variabel & Pagi & Siang & Sore \\
\hline Temperatur $\left({ }^{\circ} \mathrm{C}\right)$ & 28 & 32 & 31 \\
Kelembaban $(\%)$ & 88 & 86 & 89 \\
\hline
\end{tabular}

Keterangan : Pagi hari (08.00 WIB), Siang hari (12.00 WIB) dan Sore (16.00 WIB).

Hasil pengukuran suhu selama penelitian pada pagi hari yaitu $28^{\circ} \mathrm{C}$, siang hari yaitu $32^{\circ} \mathrm{C}$ dan sore hari $31^{\circ} \mathrm{C}$. Rataan suhu selama penelitian yaitu $28-32^{\circ} \mathrm{C}$. Rataan kelembaban kandang selama penelitian yaitu 87\%. Temperatur selama penelitian ini sejalan dengan penelitian Hutagalung (2018) yang menyatakan bahwa temperatur kandang pada penelitian kambing PE yaitu $27-32^{\circ} \mathrm{C}$. Suhendro (2018) melaporkan bahwa kelembaban kandang kambing selama penelitian berkisar antara 79,69-91,93\%. Berdasarkan tersebut kelembaban pada penelitian ini masih dalam kisaran normal yaitu $86-89 \%$.

\section{KESIMPULAN DAN SARAN}

Dapat disimpulkan bahwa pemberian pakan fermentasi ampas tahu dan bungkil inti sawit meningkatkan kecernaan serat kasar dan tidak meningkatkan kecernaan protein kasar. Namun memberikan kecernaan protein kasar yang lebih baik dengan level pemberian ampas tahu $35 \%$ dan bungkil inti sawit sebesar $10 \%$.

Sebaiknya adanya penelitian lanjutan dengan pemberian bungkil inti sawit $10 \%$ dalam ransum dengan mempersingkat lama fermentasi pakan sehingga kandungan protein kasar semakin tinggi.

\section{UCAPAN TERIMAKASIH}

Penulis mengucapkan terimakasih kepada PT Indofood Sukses Makmur Tbk., yang telah mendanai penelitian ini melalui program Indofood Riset Nugraha 2018/2019, dengan nomor kontrak [NO. SKE. 517/CC/VIII/2018].

\section{DAFTAR PUSTAKA}

Alimon, A. R. 2004. The nutrive value of palm karnel cake for animal feed. https://www.researchgate.net/publicat ion/242540604. 04 Maret 2019.

Allen, M. S. and Y. Ying. 2012. Effects of Saccharomyces cerevisiae fermentation product on ruminal strach digestion are dependent upon dry matter intake for lactating cows. Journal of Dairy Science 95 (11) : 6591-6605.

Aregheore, E. M. 2000. Chemical composition and nutritive value of some tropical by-product feedstuffs for small ruminants in vivo and in vitro digestibility. Animal Feed Science and Tecnology. 85 : 99-109.

Aryanto, B. Suwignyo, dan Panjono. 2013. Efek pengurangan dan pemenuhan kembali jumlah pakan terhadap konsumsi dan kecernaan bahan pakan pada kambing kacang dan Peranakan Etawa. Buletin Peternakan 37 (1): 1218. 
Astuti, M. 2007. Pengantar Ilmu Statistik untuk Peternakan dan Kesehatan Hewan. Binasti Publisher, Bogor.

Bintang, I. A. K., A. P. Sinurat, T. Mutiasari, T. Pasaribu, T. Purwadaria, dan T. Haryati. 1998. Penggunaan bungkil inti sawit dan produk fermentasi dalam ransum sedang bertumbuh. Jurnal Ilmu Ternak dan Veteriner. 4 (3) : 179-185.

Carvalho-Castro, G. A., C.O. Lopes., C. A. G. Leal, P. G. Cardoso, R. C. Leite and H. C. P. Figueirendo. 2010. Detection of type III secretion system genes in aeromonas hydrophila and their relationship with virulence in nile tilapia. Veterinary Microbiology. $144: 371-376$.

Cherdthong, A., B. Pornjantuek and C. Wachirapakorn. 2016. Effect of feeding Cassava bioetanol waste in nutrient intake, digestibility and rumen fermentation in growing goats. Journal Tropical Animal Health Prodroduction. 48 (7) : 1369-1374.

Ditjen Perkebunan. 2016. Statistik Perkebunan Indonesia. Direktorat Jenderal Perkebunan Republik Indonesia. Hal : 19-26

Ditjen PKH. 2017. Statistik Peternakan dan Kesehatan Hewan. Direktorat Jenderal Peternakan dan Kesehatan hewan Kementerian Pertanian Republik Indonesia. Hal : 120.

Duldjaman, M. 2004. Penggunaan ampas tahu untuk meningkatkan gizi pakan domba lokal. Media Peternakan. 27 (3) : 107-110.

Elita, A. S. 2006. Studi perbandingan penampilan umum dan kecernaan pakan pada kambing dan domba lokal. Skripsi. Fakultas Peternakan. Institut Pertanian Bogor, Bogor.
Fisman, E. 2000. Kecernaan BK, BO, dan PK ransum yang terdiri dari gamal (Glirisida, sp) dan hay ubi kayu (Manihot, sp) pada kambing PE. Skripsi. Jurusan Peternakan Fakultas Pertanian. Universitas Bengkulu, Bengkulu.

Gabriel, O. S., A. N Fajemisin and E. Onyaekachi. 2018. Nutrients digestibility, nitrogen balance and blood profile of West African Dwarf (Wad) goats fed Cassava Pels. with urea-molasses multi-nutrient blok (UMMB) suplements. Asian Research Journal of Agriculture. 9 (4) : 1-11.

Gultom, E. P., T. H. Wahyuni dan M. Tafsin. 2016. Kecernaan serat kasar dan protein kasar ransum yang mengandung pelepah daun kelapa sawit dengan perlakuan fisik, biologis, kimia dan kombinasinya pada domba. Jurnal. Peternakan Integratif. 4 (2) : 193-202.

Hutagalung, L. W. 2018. Kecernaan protein kasar dan serat kasar kambing Peranakan Etawa yang diberi pakan fermentasi lumpur sawit dan ampas tahu dengan imbangan yang berbeda. Skripsi. Jurusan Peternakan Fakultas Pertanian. Universitas Bengkulu, Bengkulu.

Ibrahim, M. N. M., S. Tamminga and G. Zemmelink. 1995. Degradation of Trofical roughages and concentrate feeds in the rumen. Animal Feed Science and Tecnology. 54 : 81-92.

Isnainiyati, N. 2001. Pengunaan jerami padi fermentasi dan kombinasi jerami padi silase rumput raja sebagai pakan basal serta pengaruhnya terhadap pertambahan bobot badan harian dan kualitas daging sapi peternakan Ongole. Program Pascasarjana Ilmu Peternakan, Fakultas Peternakan. Universitas Gadjah Mada, Yogyakarta. 
Lu, C. D., J. R. Kawas, and O. G. Mahgoub. 2005. Fiber digestion and utilization in goats. Small Ruminants Research $6: 45-52$

Mathius, I. W., dan A. P. Sinurat. 2001. Pemanfaatan bahan pakan inkonvensional untuk ternak. Wartazoa. 11 (2) : 20-31.

McDonald, P., R. Edwards, J. Greenhalgh, and C. Morgan. 2002. Animal nutrition. 6th edition. Longman Scientific and Technical, New York, Morand.

Morand-Fehr, P. 1981. Nutrition and Feeding of Goats: Application to Temperate Climatic Conditions in Goat Production. In C. Gall (Ed): Academic Press, New York, NY.

Nuraini. 2009. Performa broiler dengan ransum mengandung campuran ampas sagu dan ampas tahu yang difermentasi dengan Neurospora crassa. Media Peternakan. 32 (3) : 196-203.

Paramita, W. L., W. E. Susanto, dan A. B. Yulianto. 2008. Konsumsi dan kecernaan bahan kering dan bahan organik dalam haylase pakan lengkap ternak sapi peranakan Ongole. Media Kedokteran Hewan. 24: 59-62.

Pelczar, M. J. dan E.C.S. Chan. 1988. Dasar-dasar Mikrobiologi. Jilid ke-1. Hadioetomo, R. S., Imas, T., Tjitrosomo, S. S., Angka, S. L., penerjemah. UI Press. Terjemahan dari : Elements of Microbiology, Jakarta.

Puastuti, W. 2005. Tolok ukur mutu protein ransum dan relevansinya dengan retensi nitrogen serta pertumbuhan domba (Disertasi S3). Institut Pertanian Bogor, Bogor.

Rahman, M. M., R. B Abdullah, W. E. Wan Khadijah., T. Nakagawa and R. Akashi. 2013. Feed intake, digetibility and growth performance of goats offered napier grass suplemented with molasses proctected palm karnel cake and soya waste. Asian Journal of Animal and Veterinary Advances. 8 (3) : 527-534.

Rashid, M. 2008. Goats and theirs nutrition. Manitoba Goats Associaction. www.manitobagoats.ca. Diakses pada tanggal 8 Maret 2019.

Suhendro. 2018. Pengaruh penggunaan bungkil inti sawit dan bungkil inti sawit fermentasi pengganti ampas tahu dalam ransum terhadap pertumbuhan Kambing Nubian Dara. Skripsi. Jurusan Peternakan Fakultas Pertanian, Bengkulu.

Yan, T., J. P. Frost, T. W. J. Keady, R. E. Agnew and C. S. Mayne. 2007. Prediction of nitrogen excretion in feses and urine of beef cattle offered diets containing grass silage. Journal Animal Science. 85 : 1982-1989. 